\title{
ДІЯЛЬНІСТЬ ОДЕСЬКОГО МУНІЦИПАЛІТЕТУ ТРАНСНІСТРІЇ (1941-1944 pp.)
}

Анотація. У статті досліджується діяльність Одеського муніципалітету в період румунської окупації Одеси в 1941-1944 рр. Доведено, що діяльність муніципалітету сконщентрувалася, головним чином, на таких аспектах: реформування адміністративної гілки управління, відновлення економіки, реформування органів правопорядку, охорони здоров'я та освіти.

Також перед урядовиями Одеського муніципалітету стояло дуже складне завдання по відновленню більш-менш нормального функціонування міста. Восени 1941 р. Одеса представляла собою жахливу картину після військових дій: підірвана електростанція, зруйнований водопровід, радіостаниія, телефонна станція, розграбовані магазини, розбиті склади, хлібозаводи та млини, згарища будинків, зіпсовані мостові, зруйновані лікувальні установи.

Встановлено, що протягом 1941-1944 рр. урядовиям муніщипалітету вдалося: відновити електропостачання та трамвайний рух, налагодити постачання води та продовольство у місто, в декотрій мірі відновити зруйновану економіку, провести фінансову реформу, відкрити медичні установи, реформувати шкільну освіту, налагодити поштовий зв'язок тощо.

Ключові слова: Друга світова війна, окупація, Трансністрія, Одеський муніципалітет, пре$c a$

Ще донедавна багато аспектів діяльності окупаційних органів управління залишалася поза увагою дослідників, але в останній час ця тенденція змінилася: в українській історіографії все більше з'являється наукових праць, які стосуються періоду німецької та румунської окупації українських земель у роки Другої світової війни. Сталося це через те, що у радянський період ця тема довгий час замовчувалася, науковці не мали доступу до архівних фондів (у тому числі і засекреченої окупаційної преси) і не могли об'єктивно розглянути дані питання.

На сучасному етапі значний внесок у дослідження даної тематики вніс одеський дослідник М.I. Михайлуца ${ }^{1}$, який у своїх багаточисленних працях розглянув різні аспекти діяльності румунського режиму на Півдні України: від релігійної до пропагандистської політики. У 2010 р. виходить друком фундаментальна праця «Україна в Другій світовій війні: погляд з XXI століття», де чільне місце займає розділ відомих одеських істориків

\footnotetext{
* Біліченко Лідія Сергіївна - магістр історії. Чорноморський національний університет імені Петра Могили (м. Миколаїв); ORCID: https://orcid.org/0000-0001-5547-9248; e-mail: bilichenko.lidia@gmail.com

${ }^{1}$ Михайлуиа M.I. Релігійна політика румунської окупаційної влади в Південній Бессарабії і Трансністрії (кінець 1930 - 1944 рр.). Одеса, 2006. 237 с.; Михайлуца М.І. Відображення процесу формування і участі у боях «Русской освободительной армии» (РОА) на сторінках трансністрійської преси // Сторінки воєнної історії України: зб. наук. статей / [відп. ред. В. А. Смолій] / НАН України, Ін-т історії України. Київ, 2010. Вип. 13. C. 100-106.
} 
(Т. Вінцковський, М. Михайлуца, Г. Казимова, В. Щетніков) під назвою «Окупаційний режим в губернаторстві «Трансністрія» ${ }^{2}$, до досить детально описує основні напрямки діяльності румунської адміністрації на окупованих територіях. Питання органів правопорядку в роки німецько-румунської окупації Півдня України дослідив С.М. Боган ${ }^{3}$, а культурній політиці румунської адміністрації чимало праць присвятила Н.В. Шевченко ${ }^{4}$. Становище сільської громади на окупованій території ретельно вивчає одеський історик О.В. Осипенко ${ }^{5}$.

3 огляду на те, що особливе стратегічне та політичне значення як для румунською влади, так і для радянського керівництва, протягом війни посідало місто Одеса, варто відзначити, що на сьогоднішній момент у вітчизняній історичній науці немає узагальнюючих робіт стосовно діяльності Одеського муніципалітету протягом 1941-1944 рр. Виходячи $з$ вищесказаного, автор ставить за мету на основі як узагальненого наявного історіографічного надбання, так і шляхом залучення нового матеріалу (періодика, архівні джерела) розкрити механізм діяльності румунсько-фашистських адміністративних органів на території Одеси.

Для проведення цього дослідження, насамперед, були використані матеріали як трансністрійських, так і діаспорних газетних видань. Зокрема, газети: «Самбірські вісті», «Одесская газета», «Наше слово», «Голос», «Нова доба (Берлін)», «Молва», в яких досить детально описується економічна, культурна, правоохоронна політика окупаційної влади на території Одеси.

До кінця жовтня 1941 р. Південь України був майже повністю окупований німецько-румунськими військами 6.19 серпня 1941 р. внаслідок спеціального договору між німецькими та румунськими уповноваженими, підписаного в Тягині, всю територію між Бугом і Дністром було віддано румунській адміністрації, під назвою «Трансністрія». 29 вересня 1941 р. у Тирасполі склав присягу новообраний губернатор Трансністрії професор Георге Алексяну. У своїй промові губернатор підкреслив, що «...Уряд Трансністрії має перед собою велике завдання своїми діями та працею досягти перемоги у військовій кампанії на Сході і відіграти вирішальну роль у новому будівництві...» Присяга завершилася принесенням подяки нацистському та фашистському вождям Німеччини та Італії ${ }^{7}$

За наказом новопризначеного губернатора, територія Трансністрії була розділена на 13 адміністративних повітів, які управлялися повітовими префектурами на чолі з голо-

\footnotetext{
${ }^{2}$ Вінцковський Т., Кязимова Г., Михайлуца М., Щетніков В. Окупаційний режим в губернаторстві «Трансністрія» // Україна в Другій світовій війні: погляд з XXI століття. Історичні нариси. Кн. 1. Київ, 2010. С. 413-445.

${ }^{3}$ Боган С. Колабораціоністські органи правопорядку на Півдні України у 1941-1944 pp. // Наукові праці [Чорноморського державного університету імені Петра Могили]. Сер.: Історія. 2012. Т. 180, Вип. 168. С. 35-40.

${ }^{4}$ Шевченко Н.В. Діяльність нащіональних культурно-освітніх закладів Півдня України в період румунської окупації 1941-1944 рр.: автор. дис.... к. іст. н. Миколаїв, 2010. 16 с.

${ }_{5}^{5}$ Осипенко О.В. Фіскальна політика румунських окупантів щодо сільського населення в південно-західних землях України (1941-1944 рр.) // Краєзнавство. 2017. № 1-2. С. 184-191; Осипенко О.В. Система управління сільським господарством у губернаторстві «Трансністрія» (1941-1944рр.) // Емінак: щоквартальник науковий. 2015. № 4 (12) (жовтень-грудень). С. 64-71.

${ }^{6}$ Михайлуца М., Тригуб О. Релігійна політика окупантів на Миколаївщині: особливості, суть та наслідки (серпень 1941 - березень 1944 рр.) // Краєзнавство. 2014. № 1. С. 113.

${ }^{7}$ У звільненій Трансністрії // Самбірські вісті (Самбор). 1941. 26 жовтня (№ 24). С. 1.
} 
вами адміністрацій - префектами 8 . у містах, що входили до складу Губернаторства Трансністрії, також були свої адміністративні органи - примарії. Після здобуття Одеси, як повідомляла газета «Самбірські новини», провідник румунської держави Антонеску видав декрет, яким включив Одесу з її околицями до Трансністрії та проголосив її столицею цілої губернії. Також, Одеса була виділена в окремий муніципалітет і примарія цього муніципалітету підпорядковувалася безпосередньо губернаторові. Генеральний примарем Одеського муніципалітету було призначено Германа Пинтю, а сенатори Володимир Кіореску й Елефтерія Сінікліу стали бурмістрами. Заступниками Генерального примаря було обрано В.К. Кіореску, .І. Сінікліу, К.В. Відрашку, проф. В.І. Кунверта, проф. Н.Н. Заєвлоші, а генеральним секретарем став А.К. Костінеску9 .

Згідно наказу Губернатора Трансністрії від 18 жовтня 1941 р. на території Одеси засновуються наступні дирекції: фінансова дирекція, дирекція постачання, дирекція промислових підприємств, інвентарна дирекція, водопровідна та каналізаційна дирекція, електротехнічна дирекція, трамвайна дирекція, земельна дирекція, дирекція експлуатації рухомого і нерухомого майна, шкільно-культурна дирекція, медико-санітарна та громадського піклування дирекція, дирекція відділів та актів цивільного стану і нотаріальними справами, інженерно-технічна дирекція, дирекція по очищенню міста і транспортна дирекція.

3 метою своєчасного вирішення всіх питань і справ у головних управліннях Муніципалітету, починаючи з 24 листопада 1941 р., керівництво та контроль над роботою управлінь (дирекцій) муніципалітету Одеси розподіляється між помічниками міського голови таким чином: 1. Кіореску Володимир бере відомства: а) фінансова дирекція; 6) дирекція постачання; в) дирекція промислових підприємств. 2. Сінікліу Елефтерій: а) інвентарна дирекція; б) водопровідна і каналізаційна дирекція; в) електротехнічна дирекція; г) трамвайна дирекція; д) земельна дирекція. 3. Відрашку Костянтин: а) дирекція експлуатації рухомого і нерухомого майна; б) шкільно-культурна дирекція. 4. Професор Заєвлоші Михайло: а) медико-санітарна та громадського піклування дирекція; б) дирекція відділів та актів цивільного стану і нотаріальними справами. 5. Професор Володимир Кунверта: а) інженерно-технічною дирекцією; б) дирекцією по очищенню міста та дирекцією транспорту ${ }^{10}$.

Перед урядовцями Одеського муніципалітету стояло дуже складне завдання по відновленню більш-менш нормального функціонування міста. За повідомленням «Одеської газети», Одеса представляла собою жахливу картину після військових дій: підірвана електростанція, зруйнований водопровід, радіостанція та телефонна станція, розграбовані магазини, розбиті склади, хлібозаводи та млини, дим від згарищ, зіпсовані мостові, трупи людей і коней на вулицях, розбиті аптеки, зруйновані лікувальні установи.

Згідно постанови № 6 Одеського муніципалітету:

\footnotetext{
${ }^{8}$ Документи Державного архіву Одеської області з історії Другої світової війни та ії наслідків: огляд фондів // ДАОО; Уклад.: Л. Білоусова, О. Гейтан, В. Деречина, С. Желясков, О. Мартиненко, С. Маковецька, Г. Малінова, О. Набока, Н. Філіпченкова, В. Харковенко. Одеса, 2009. С. 2.

${ }^{9}$ У звільненій Трансністрії // Самбірські вісті (Самбор). 1941. 26 жовтня (№ 24). С. 1.

${ }^{10}$ Постановление № 12 Муниципалитета г. Одессы // Одесская газета (Одесса). 1941. 26 ноября (№ 11). С. 5.
} 
«3 метою забезпечення якнайшвидшого розбирання барикад і приведення вулиць міста в належний вигляд: 1) Всі працездатні жителі Одеси у віці від 18 до 50 років (включно) залучаються до громадських робіт по приведенню вулиць міста у належний вигляд; 2) Про початок робіт по кожній вулиці жителі будуть сповіщені міським муніципалітетом через керуючих будинками і двірників; 3) Всі роботи будуть проводитися за вказівками і під наглядом міського муніципалітету; 4) Всі, хто беруть участь у роботах отримають про те відповідні довідки; 5) Ті, хто ухиляється від робіт, згідно цієї постанови, будуть притягнуті до суворої відповідальності..." ${ }^{11}$.

Одразу, після оголошення постанови, під керівництвом начальника технічного відділу муніципалітету, населення міста було залучене до розбирання барикад.

Румунській адміністрації за короткий період і в умовах воєнного часу вдалося відновити електропостачання. Зокрема, було відновлено турбогенератор і парові котли, проведені роботи по реконструкції зруйнованих будівель Центральної станції.

Також протягом чотирьох місяців було закінчено роботи по відновленню передавальних апаратів на довгій хвилі. Були виправлені короткохвильові передатчики потужністю в 1 кВт. Завершилися роботи по відновленню центрального приміщення радіостанції та запрацювали установки для передачі новин у Тирасполь. Була відновлена і міська радіомережа, яка передавала новини, інформацію, музику, оперні спектаклі. Проведена інвентаризація матеріалів, знайдених в електротехнічних складах.

Важливе було питання і трамвайного руху. Для відновлення трамвайного руху були проведені роботи з ремонту вагонів. 3400 наявних вагонів - 120 були приведені у порядок. Організовано їдальні та лавки для робітників трамвая.

Життєво необхідним було вирішення проблеми постачання води у місто. Зокрема, на станції «Дністер» були проведені поточні ремонтні роботи; станції № 1 і 2 підтримувалися у стані готовності до регулярної подачі; відремонтовано нафтокачку на станції «Вигода»; на водопроводах великого діаметра ліквідовані розриви у 14 місцях; в l міській мережі так само ліквідовані пошкодження трубопроводів.

На станції «Чумка» проведено капітальний ремонт натискної машини № 1 і поточним ремонтом станція підтримувалася у стані готовності для регулярної роботи. Періодично, при подачі води зі станції «Дністер», станція «Чумка» давала воду в міську мережу. Для підсобного водопостачання (з колодязів і свердловин на території міста) функціонували 35 свердловин і 9 шахтних колодязів. Були сформовані тарифи на воду та проведена інкасація грошей ${ }^{12}$.

Одеський муніципалітет взявся також і за перейменування вулиць, здійснивши так звану «декомунізацію». Так, наприклад, «Вулиця Х-річчя Червоної Армії» (дореволюційна назва - «Преображенська») відтепер носила назву «вулиця Короля Міхая I», «Вулиця Карла Маркса» (дореволюційна назва - «Катерининська») отримала назву «Вулиця Адольфа Гітлера», «Вулиця Чичеріна» (дореволюційна назва - «Успенська») офіційно іменувалася

\footnotetext{
${ }^{11}$ Одесские баррикады // Одесская газета (Одесса). 1941. 11 ноября (№ 6). С. 2.

${ }^{12} 16$ октября 1941 - 16 октября 1943. Два года плодотворной деятельности Одесского Муниципалитета // Одесская газета (Одесса). 1943. 16 октября (№ 240). С. 3.
} 
«вулиця Маршала Іона Антонеску» ${ }^{13}$ (детальніше див. статтю М. Михайлуци «“Десталінізація” та “декомунізація" в Одесі (1941-1943рр.): мета, методи й акценти»"14).

У сфері фінансової реформи було проведено обмін радянських грошових знаків на марки (РККС): 11807 осіб (глав сімейств) обміняли 812137 марок, 21302 робітників і службовців установ і фабрик - 980 542, всього 33109 сімейства обміняли 1792679 марок, що дорівнювало 35853580 рублів. Для інкасування різних податків і такс була вироблена низка заходів, а саме: а) місто розділене на райони; б) складено план для з'ясування можливості стягнення місцевих податків і такс; в) розроблено проект оподаткування кустарів, збору внесків за патенти і податку на нерухоме майно; г) організована апеляційна комісія; д) організовані муніципальні каси у всіх районах; е) встановлена базарна такса. При Фінансовому управлінні організований Банківський відділ, який, проводив розрахунки між різними міськими установами. Вжиті всі заходи для нормалізації індустріального, комерційного, культурного й адміністративного життя, при посередництві видачі дотацій відповідним установам ${ }^{15}$.

3 метою поліпшення фінансового стану міста, Одеський муніципалітет 22 січня 1942 р. видав резолюцію за № 52 щодо податків за приміщення:

«...маючи на увазі доповідну записку пана В. Кіореску, помічника міського голови, представлену мені і пану Генеральному секретарю та висновок Фінансової дирекції муніципалітету, дане примарем, щодо податків на приміщення, наказує що, що з 1 січня 1942 р. Одеським муніципалітетом встановлюється податок на приміщення в такому порядку: податок стягується з житлових приміщень, зайнятих жителями міста, з приміщень, зайнятих підприємствами комерційного та промислового типу, фабриками, театрами, лазнями. Згідно ст. 2 податок стягується з усіх приміщень, що належать державі, Одеському муніципалітету, всякого роду установам, підприємствам, товариствам і приватним особам.

За ст. 3 від податку звільняються: а) приміщення, що належать державі або муніципалітету, віддані в оренду; б) приміщення, зайняті військовими властями; в) приміщення, що належать державі або муніципалітету й іншим установам , зазначеним у ст. 2, або належать повністю чи частково культурним і благодійним товариствам.

Ст. 4 передбачала, що податок на приміщення стягується у наступному розмірі:

а) 3 житлових будинків, розташованих у 1-му поясі - 20 пф. за 1 квадратний метр, розташованих у 2-му поясі - 15 пф. за 1 кв. метр;

б) 3 театрів, кінотеатрів та інших видовищних підприємств, 3 промисловокомерційних підприємств, зі складів без знижки на ремонт та обладнання приміщень, покладене на орендарів;

в) 3 фабрик, заводів, лазень з розрахунку 0,5\% вартістю не рухомого майна по балансу, мінус вартість машин і установок.

Ст. 5: Податок стягується по півріччях: за 1 півріччя він вноситься до 1 березня, за II до 1 вересня $1942 \mathrm{p}$.

Ст. 6. За несплату в термін стягується пеня в розмірі $23 \%$ в день 3 несплаченої суми.

\footnotetext{
${ }^{13}$ Постановление № 8 // Одесская газета (Одесса). 1941. 26 ноября (№ 11). С. 5.

${ }^{14}$ Михайлуца М. «Десталінізація» та «декомунізація» в Одесі (1941-1943 рр.): мета, методи й акценти // Емінак. 2016. № 2 (1). С. 65-71.

${ }^{15}$ Обзор деятельности Одесского Муниципалитета с 17-го октября 1941 г. до 1 марта 1942 года // Одесская газета (Одесса). 1942. 11 марта (№ 50). С. 5.
} 
Ст. 7. Розмір податку визначає Фінансова дирекція, куди і буде вноситися податок» ${ }^{16}$.

Варто відзначити, що не дивлячись на закон про податки, протягом 1941-1942 pp. в Одесі відкрилися 633 комерційних і промислових підприємства, а також 358 майстерень різних ремісників. Здано приватним особам 23 металообробних підприємств, 5 хімічних підприємств, 16 підприємств будівельних матеріалів, одне трикотажне підприємство, 24 харчових підприємства.

Запрацювали і фабрики. Зокрема, відновили свою діяльність: трикотажна фабрика, текстильні фабрики 1, 2 і 4, пивоварний завод, склозавод, миловарний завод, суперфосфатний завод, деревообробної фабрика, ліжковий завод, канатна фабрика, фабрика ваг, картонажна фабрика, паперова та палітурна фабрики. Ці підприємства виробляли щомісяця товарів приблизно на 145000 марок. Зокрема, трикотажна та ліжкова фабрики працювали для армії.

Дуже важливим питанням було питання продовольства. Станом, на січень-лютий 1942 р. на території Одеського муніципалітету працювали наступні підприємства: хлібозавод № 1, макаронна фабрика, фабрика дріжджів, комбікормовий млин, млин для очистки пшона, фабрика рибних консервів, маслозавод, фабрика цукерок, халви та мармеладу. Також було відкрито фабрику бісквітів і тістечок, організовано 15 колоніальних і бакалійних магазинів, а також 14 магазинів з різними предметами домашнього побуту та декілька паперових магазинів. Дирекція постачання мала також 8 складів для зберігання товарів і різних матеріалів, необхідних для підприємств ${ }^{17}$.

Дирекція агрокультури Губернаторства Трансністрії на початку 1942 р. дала розпорядження про відвантаження в Одесу 50 вагонів пшениці з Болтянского повіту і 50 вагонів пшениці з Жугастровского повіту для забезпечення безперебійного постачання міста хлібом. Генерал-інженер пан Василіу передав для експлуатації муніципалітетом консервні заводи № 1 і 2, маслоробний завод № 2 і миловарний завод. Продукція цих заводів у подальшому використовувалася, у першу чергу, для потреб армії. Також, за вказівкою міського голови Одеського муніципалітету Германа Пинті у недільні та святкові дні продаж хліба у магазинах муніципалітету (за картками) не проводився. Хліб, належний до видачі у ці дні, відтоді видавався завжди напередодні свят ${ }^{18}$.

17 травня 1942 р. спеціальним літаком з Тирасполя на аеродром с. Татарка, а потім до Одеси прибули високі гості: статс-секретар Третього Рейху і за сумісництвом секретар Маршала Геринга доктор Неуман разом з Губернатором Трансністрії проф. Г. Алексяну. Статс-секретар прибув разом з міністерським радником Каджіером, урядовим радником фон Себбеке, доктором Альбертом і німецьким генералом Роткірхом. Метою їхнього візиту було інспектування й огляд діяльності Одеського муніципалітету по відбудові міста. 3 аеродрому гості вирушили в Одеський міський театр опери та балету, де їм показали фрагменти опер «Царська наречена», «Євгеній Онєгін» і «Князь Ігор». На наступний день, 18 травня пан Неуман відвідав заводи, електростанцію й інші підприємства й установи

\footnotetext{
${ }^{16}$ Постановление № 52 Одесского Муниципалитета // Одесская газета (Одесса). 1942. 31 января (№ 34). С. 4.

${ }^{17}$ Обзор деятельности Одесского Муниципалитета с 17-го октября 1941 г. до 1 марта 1942 года // Одесская газета (Одесса). 1942. 11 марта (№ 50). С. 5.

${ }^{18}$ В Одесском Муниципалитете // Одесская газета (Одесса). 1942. 19 мая (№ 83). С. 3.
} 
міста. У цілому високі гості були задоволені проробленою роботою Одеського муніципалітету ${ }^{19}$.

Ще однією проблемою, яка повстала перед урядовцями Одеського муніципалітету, стало санітарне очищення міста. Зокрема, наявних машин і коней було зовсім недостатньо для задоволення потреб по очищенню міста, що знаходилося у дуже поганому санітарному стані. До того ж було недостатньо бензину для регулярної роботи машин ${ }^{20}$. За постановою № 7 Одеського Муніципалітету:

«Для приведення міста у належний санітарний стан і попередження виникнення і поширення епідемічних хвороб наказуємо:

1) Під відповідальність керуючих будинками та двірників, негайно приступити до очищення дворів і тротуарів від побутового сміття. Зазначене очищення закінчити до 25 жовтня $1941 \mathrm{p}$.

2) Начальникам районних префектур мобілізувати для цієї мети всі наявні в місті у приватних осіб, установ і підприємств перевізні засоби. В якості робочої сили залучити усе чоловіче населення дворів, у вільний від роботи час в установах, віком від 18 до 50 років.

3) Встановити, тимчасово, наступні 2 звалища, куди необхідно звозити сміття: Куяльницька дорога та територія поблизу тюрми. Вивозити сміття на інші місця категорично забороняється.

4) Привести у належний стан водостічні труби будинків, відливи та стоки, відремонтувати дворові вбиральні, виправити водопровідні дворові крани.

5) Заборонити відкриття харчових підприємств, ресторанів, торгових одиниць, складів, перукарень, лазень і т. д. без спеціального дозволу медико-санітарного відділу міської управи.

6) Всі лікарі зобов'язані протягом 24 годин сповіщати медико-санітарний відділ про кожного поступаючого до них хворого, випадки інфекційного захворювання, а також про кожний випадок смерті. Мешканці будинків при виявленні ними підозрілого випадку інфекційного захворювання повідомляють про нього уповноваженому будинку або у поліклініку.

7) Відповідальність за виконання цієї постанови покладається на районні префектури, а за санітарний стан дворів - на уповноважених дворів або двірників.... ${ }^{21}$.

Згідно наказу Губернатора Трансністрії від 27 травня 1943 р., який повинен був привести до виконання міська поліція, санітарний відділ і шефи секторів, усі жителі до 10 липня 1943 р. повинні відремонтувати та побілити свої будинки. При кожному дворі має бути збудований клозет не менше ніж до 2 м глибиною, який мав бути побілений як ззовні так і всередині. Кожний мешканець повинен викопати у глибині свого подвір'я вигрібну яму, куди мало викидатися сміття ${ }^{22}$.

У напрямку медицини й охорони здоров'я, у першу чергу, було створено 2 інфекційних шпиталі, відновлена лікарня на 800 ліжок і відкрито 3 пологових будинки. Вже станом на 1944 р. у медичному відділі медико-санітарної дирекції функціонували

\footnotetext{
${ }^{19}$ Ibidem.

${ }^{20}$ Обзор деятельности Одесского Муниципалитета с 17-го октября 1941 г. до 1 марта 1942 года // Одесская газета (Одесса). 1942. 11 марта (№ 50). С. 5.

${ }^{21}$ Постановление № 7 Муниципалитета г. Одессы // Одесская газета (Одесса). 1941. 20 ноября (№ 9). С. 2.

${ }^{22}$ Державний архів Миколаївської області. Ф. Р-1651. Оп. 1. Спр. 3. Арк. 24.
} 
6 лікарень, 13 поліклінік, 2 пологових будинки, 1 амбулаторія, 2 диспансери, 2 дитячих консультації та 10 інших установ. Було прийнято у лікарні 5584 хворих. У пологових будинках було зареєстровано 105 народжень. Поліклініки й інші медичні установи пропустили 99219 хворих, надавши 245124 консультації, з яких на дому 15 666. Було дано 127628 безкоштовних медичних консультацій в установах і 11884 безкоштовних відвідувань лікарями вдома. Швидка допомога надала медичну допомогу у 1046 випадках. За розпорядженням шкільного медичного інспектора були інспектовані початкові школи й оглянуто 34618 школярів. Шкільні поліклініки дали 10248 консультацій 3094 школярам. У венерологічному відділі функціонували 2 венеричних диспансери та 6 пунктів, встановлено 62 випадків туберкульозу ${ }^{23}$.

Досить жорстка політика румунського керівництва була стосовно домашніх тварин (зокрема собак). Так згідно наказу № 50 Одеського Муніципалітету:

«...Всі власники собак зобов'язані зареєструвати їх у районних ветеринарних відділах, де вони отримають номер, який повинен бути привішений на шию собаці. 2) Власники собак повинні платити щорічно збір у розмірі 2 марок за першу собаку, а за інші - по 5 марок кожна. 3) Фермери, які живуть ізольовано на околицях міста, не платять збір за першу собаку. За наступні ж по 3 марки з собаки. 4) 3бір вноситься наперед до районних ветеринарних відділів. 5) Не сплативши вищевказаного збору громадяни, повинні здати собак на собакобійню. 6) Всі собаки, знайдені без знака і номера на шиї, будуть забиратися та знищуватися. 7) Вільно випускатися на вулицю можуть тільки собаки у наморднику й ошийнику. 8) Особи, які випускають собак на вулицю без намордника і нашийника караються штрафом від 20 до 50 марок, у випадку повторення - від 50 до 100 марок. 9) Штрафи від 20 до 50 марок накладаються ветеринарною дирекцією муніципалітету, а від 50 до 100 марок - преторією одеської жандармерії. 10) Порушення будуть констатуватися органами ветеринарної дирекції, а також судовою, громадянською і військовою поліцією...» ${ }^{24}$.

Діяло на території Одеського Муніципалітету також цивільне і військове судочинство. Так, згідно наказу Одеського муніципалітету № 37 від 1942 р.:

«... 1. Кара Правосуддя здійснюється через Преторати і Військовий суд. У кожному повіті буде функціонувати преторат, у складі, зазначеному в Зводі військових законів. Кількість і район дії Військових судів визначається командуванням армією. § 2. Преторати судять всіх громадян, які вчинили один з наступних проступків: непокора наказам, даними Губернаторством Трансністрії, військовим командуванням, повітовим префектом і міською управою. Провини, передбачені загальним і спеціальним кримінальним правом, коли відповідне покарання не перевищує 2-х років в'язниці і 20000 лей штрафу. § 3. Військові Суди судять всі злочини і проступки проти загального та спеціального кримінального Кодексу, коли покарання перевищує 2 роки в'язниці і 10000 лей штрафу. § 4. Преторати і Військові суди організовуються та функціонують відповідно до вказівок Кодексу військових законів. При кожному жандармському управлінні Трансністрії організовується Повітовий військовий преторат; посаду повітового військового претора виконує начальник відповідного Жандармського управління. Рішення Претораторів і Військових судів остаточне. § 5. Виконання постанов Військового суду і Претораторів проводиться відповідно до приписів Зводу війсь-

\footnotetext{
${ }^{23}$ Обзор деятельности Одесского Муниципалитета с 17-го октября 1941 г. до 1 марта 1942 года // Одесская газета (Одесса). 1942. 11 марта (№ 50). С. 5.

${ }^{24}$ Муниципалитет г. Одессы приказ № 50 // Одесская газета (Одесса). 1942. 30 июня (№ 110). С. 4.
} 
кових законів - нижченаведеними винятками: а) Покарання, що полягають у позбавленні волі, відбувають в арештних приміщеннях повітових міст, які засновуються й управляються повітовими префектурами, б) Штрафи стягуються інстанціями, що винесли вирок, а гроші вносяться до Головної каси Губернаторства Трансністрії...» ${ }^{25}$.

За повідомленням газети «Молва» у 1943 р. військово-польовий суд м. Одеси виніс наступні вироки: 1) Драгомирський Валентин, який проживає на Лагерній вул. № 13, засуджений на довічну каторгу за те, що будучи покликаний до священика для налагодження електропроводки, скоїв крадіжку і продав вкрадені речі на базарі; 2) Рижков Микола, засуджений до 10 років каторжних робіт за спробу крадіжки трьох валіз; 3) Поперечний Володимир, який проживає по вул. А. Гітлера № 56 , засуджений до 5 років каторжних робіт за те, що зберігав у себе зіпсований револьвер ${ }^{26}$.

Щодо органів правопорядку, то на території Одеського муніципалітету головний жандармський інспекторат і поліцейські органи підпорядковувалися губернаторові та Міністерству внутрішніх справ Румунії. Поліцейські органи складалися 3 карного відділу та таємної поліції (сигуранци). Сигуранца боролася з партизанами та підпільними диверсійними групами. Набір до поліції здійснювався 3 місцевого населення. Кожен 3 потенційних новобранців повинен був зазначити в анкеті такі відомості про себе: прізвище, ім'я, по-батькові, національність, громадянство, професію, сімейний стан, дівоче прізвище дружини, військове звання, зріст, форму обличчя, колір волосся та колір очей. Після заповнення анкети підписувалася заява, в якій зазначалося:

«Оголошую замість присяги, що подані мною дані відповідають дійсності. Заявляю далі, що я арійського походження, а саме серед моїх предків не було євреїв, та також що я не був членом комуністичної партії ${ }^{27}$.

Органи та підрозділи поліції виконували найрізноманітніші функції й обов'язки: охорона громадського правопорядку, патрулювання вулиць, постій і регулювання вуличного руху, охорона громадських закладів тощо $0^{28}$.

Займалася поліція і розслідуванням кримінальних злочинів та збройними нападами. Зокрема, за повідомленням газети «Молва» 1 березня 1943 р. о 3 годині дня Дедулям Георгій, який проживав по вулиці Ковальській, 25, при виході на вулицю був затриманий трьома озброєними грабіжниками, які, зваливши його на землю, кілька разів вистрілили 3 револьверів, цілячись йому в голову. Грабіжникам вдалося зняти з потерпілого пальто та золоте кільце, а також витягнути гаманець, в якому було 600 марок і документи. Енергійними діями районної поліції вдалося зловити зловмисників, які опинилися неповнолітніми: Широкий Михайло (16 років), Осташенко Георгій (17 років), Скакунов Леонід (17 років).

Інший випадок стався 23 березня 1943 р., коли при спробі втечі, поліцією були розстріляні «великий бандит» м. Одеси - нальотчик Іван Ананьєв, що носив прізвисько «Мо-

\footnotetext{
${ }^{25}$ Главное командование армией департамент гражданского губернатора Транснистрии приказ № 37 // Одесская газета. 1942. 22 января (№ 30). С. 4.

${ }^{26}$ Военно-полевой суд // Молва (Одесса). 1943. 26 марта (№ 94). С. 3.

${ }^{27}$ ДАМО. Ф. Р-1434. Оп. 1. Спр. 1. Арк. 5.

${ }^{28}$ Документи Державного архіву Одеської області... С. 2.
} 
рдатий», і як то кажуть «за компанію» - двірник Віктор Красовський, який його переховував у себе. Розстріл злочинців стався при наступних обставинах: злочинці розповіли органам поліції, що на одній з околиць міста ними закопані у затишному місці цінності з числа викрадених ними під час останніх нальотів. Злочинці обіцяли чинам поліції вказати місце закопаних цінностей. Однак, при виході з машини вони намагалися втекти та не звертали уваги на неодноразові попередження зупинитися. Це змусило чинів поліції, які супроводжували злочинців, відкрити вогонь, у результаті якого злочинці були вбиті ${ }^{29}$.

Ще одним напрямком роботи поліції був контроль за громадськими роботами та виконання функцій різних контрольно-ревізійних служб. За наказом № 10 губернатора «Трансністрії» поліцаї примусово виганяли усіх мешканців сіл (чоловіків, жінок, дітей) у поле для збору всіх бур'янів. Звільнялися від робіт тільки хворі, старі люди та діти віком до 6 років $^{30}$. Мешканці, які не захотіли вийти, були покарані місцевою поліцією як фізично (10 ударів батогом), так і штрафом (10 марок). Приймаючи до уваги те, що була велика потреба у фуражі для тварин (сіна, вівса, соломи та ячменю), згідно тим же наказом, мешканцям на території Одеси не дозволялося палити солому для палива. Поліція повинна було прослідкувати, аби солома була використана тільки для харчування тварин ${ }^{31}$. Також, через нестачу обмундирування солдат на фронті, з 25 жовтня 1942 р. було постановлено, що кожна родина, включаючи і німецькі сім'ї, повинна була виготовити для солдат декілька пар шкарпеток і пару перчаток. Контроль за здійсненням даної постанови було покладено на поліцію. Ті, хто не виконував зобов'язання, каралися в'язницею від 15 діб до 3-х місяців або ж штрафом у розмірі 50-100 PKKC $^{32}$.

Практикувалася й адвокатська діяльність. Зокрема, «Одесская газета» від 1 червня 1943 р. повідомляла про присягу Одеського Бюро адвокатів Генерал-губернатору Трансністрії Георге Алексяну:

«...Вчора, о 12 годині дня, в залі Воронцовського палацу відбулося принесення присяга Бюро адвокатів Трансністрії. До цього часу в зал прибув полковник Волческу, префект Одеського повіту; полковник Пововіч, префект поліції Одеси; В. Кіореску, примар Сектора, який представляв генерального примара Одеського муніципалітету; пан Чурій, генеральний інспектор Губернаторства; полковник Нікулеску, начальник служби Військового Претората. Для складання присяги були запрошені: голова Бюро адвокатів Трансністрії Костянтин Відрапсу, члени Бюро адвокати Думітреску, Моску, Стогів, Комісаржевський і Філіпеску.

Для участі у церемонії складення присяги прибули одеські адвокати: Чертков, Гримальський, Лукашев, Потапов, Дьяконов, Каймакан, а також заступник декана юридичного факультету Одеського університету - професор, доктор державного права А.А. Жилін разом 3 шістьма студентами університету.

В якості гостей присутні Генеральний Прокурор Німецького Військового Трибуналу в м. Миколаєві д-р Вебер, старший суддя д-р Зімон, суддя м. Рейц і адвокат Кошер, присутні директори Губернаторства Трансністрії, префекти повітів і представники преси...

Голова Бюро адвокатів Трансністрії Костянтин Відрапсу звернувся під час присяги до губернатора з такою промовою:

\footnotetext{
${ }^{29}$ Военно-полевой суд // Молва (Одесса). 1943. 26 марта (№ 94). С. 3.

${ }^{30}$ ДАМО. Ф. Р-1651. Оп. 1. Спр. 3. Арк. 9.

${ }^{31}$ ДАМО. Ф. Р-1651. Оп. 1. Спр. 3. Арк. 7.

32 ДАМО. Ф. Р-1651. Оп. 1. Спр. 3. Арк. 17.
} 
"Ваші розпорядження, пан Губернатор, завжди служитимуть нам керівництвом у нашій діяльності, і ми готові завжди бути Вашими скромними співробітниками, докладаючи всі наші сили, наші знання людей права, всю нашу любов до порядку і до справедливості, що настільки необхідно в сучасних обставинах, коли життя повинно бути введено у відомі правові рамки (підкорятися правовим нормам). Бюро адвокатів Трансністрії починає своє легальне існування зараз, в цей момент. Члени Бюро запевняють Вас пан Губернатор, у своій глибокій відданості і готовності включитися в суспільне життя Трансністрії, не відстаючи від ії ритму...”»"

Як зазначалося у газеті ця подія стала історичним актом у заснуванні громадянської юстиції в Трансністрії.

Діяли і нотаріальні контори. Про діяльність нотаріату Одеського муніципалітету газета «Молва» писала:

«Нотаріат Одеського муніципалітету є єдиним органом в Одесі, який має право завіряти всякого роду комерційні угоди: заповіт, дарчі записи та договірні орендно-комерційні зобов'язання. За три останні місяці було засвідчено близько 4000 різного роду документів і копій. Затверджено у правах спадщини та введені у володіння 40 осіб. Вся такса, що стягується при здійсненні актів - надходить у касу муніципалітету. Діяльністю нотаріату керує досвідчений румунський адвокат з 20-річним юридичним стажем - пан Куртов Василь. Загальне керівництво нотаріатом здійснює, директор Юридичної дирекції Одеського муніципалітету, відомий румунський адвокат - Греску Андрій»34.

3 жовтня 1942 р. був налагоджений і поштовий зв'язок. Зокрема, встановлено загальні поштові зносини в обмеженому обсязі між областями Генерального Комісаріату України й областю румунських інтересів - Трансністрією. Між німецькою та румунською адміністраціями було вирішено, що прийматимуться тільки звичайні листівки та рекомендовані листи до 20 грамів. Всі поштові відправлення мусили мати повну адресу відправника. Поштова оплата для листівки 6 пфенігів і для листів до 20 грамів - 12 пфенігів; для рекомендованих листів і листівок додавалося ще 30 пфенігів за кожне відправлення ${ }^{35}$.

Важливим кроком було реформування освіти. Відтепер початок шкільного року в Трансністрії i, зокрема, в Одесі, розпочинався 31 жовтня ${ }^{36}$. Вже станом на 10 жовтня 1942 р. функціонувало 50 шкіл 313198 учнями у віці від 8 до 13 років, і педагогічним персоналом у 550 чоловік. Всі шкільні посібники були заздалегідь переглянуті та залишені тільки необхідні. Для користування у школах була надрукувала румунська граматика. Всі школи були відремонтовані технічним відділом дирекції. Заздалегідь було вжито заходів для постачання всіх шкіл паливом. Беручи до уваги, що більшість дітей були з родин позбавлених засобів для існування і жили в бідності, при кожній школі була влаштована їдальня, де видавалися гарячі сніданки за зниженими цінами, а найбіднішим видавалися безкоштовно. Для викладання була складена аналітична програма за зразком програми в

\footnotetext{
${ }^{33}$ Исторический акт начала гражданской юстиции в Транснистрии. Губернатор Транснистрии профессор Георгий Алексяну принял присягу от Одесского Барро адвокатов // Одесская газета (Одесса). 1943. 1 июня (№ 125). С. 3.

34 Деятельность нотариата Одесского Муниципалитета // Молва (Одесса). 1943. 21 сентября (№ 238). С. 3.

${ }^{35}$ Поштове сполучення Україна-Трансністрія // Наше слово (Брест). 1942. 6 грудня (№ 35). С. 3.

${ }^{36}$ У звільненій Трансністрії // Самбірські вісті (Самбор). 1941. 26 жовтня (№ 24). С. 1.
} 
Румунському Королівстві. Особливу увагу було приділено морально-релігійному вихованню дітей. Для цього були запрошені священики, які в особливих бесідах прагнули переконати дітей, позбавлених будь-якого релігійного уявлення, про високу мораль румунської церкви ${ }^{37}$.

Знаменною подією на освітянській ниві було й відкриття Народного університету в 1942 р. у будівлі колишньої біржі 3 метою популяризації румунської культури, науки та мистецтва. Для цього були запрошені університетські професори з Румунії, які у своїх доповідях представили найцікавіші та значні проблеми з історії, географії, філософії, психології, педагогіки, літератури, права та мистецтва. Було приділено особливу увагу популяризації релігійних проблем і морально-релігійного виховання. Протягом 5 місяців було прочитано у загальному близько сотні доповідей.

Оскільки румуни у багатьох аспектах залежали від німецького керівництва, то у 1943 р. Одеський муніципалітет розіслав всім дирекціям повідомлення про те, що усім чиновникам рекомендувалося відвідувати курси німецької мови, організовані представником Німецької академії в Одесі професором Шайблером, що знаходилися на Канатній, 8. Оплата для початківців - 20 марок на місяць, і для бажаючих вдосконалитися - 10 марок на місяць ${ }^{38}$.

Віддаючи належну увагу пресі, було організовано видання румунської газети російською мовою, органу муніципалітету «Одеська газета». Газета видавалася двічі на тиждень і була важливим пропагандистським інструментом румунської адміністрації.

Дирекція культури Одеського муніципалітету в серпні 1942 р. взяла на себе реорганізацію фотокінематографічної секції. Для цієї мети вона вирішила використовувати колишню фабрику Всеукраїнського управління кінематографічної промисловості, яка дуже постраждала від бомбардування і пожеж під час військових дій. Вся апаратура й обладнання були вивезені. Таким чином вона була непридатна для роботи та потребувала капітального ремонту. Після інтенсивної роботи фабрика була частково відновлена, і виявилося можливим використовувати її для випуску документальних фільмів, що відбили багато важливих моментів 3 діяльності румунської адміністрації, Станом на 1943 р. було випущено 28 документальних фільмів: «Миколаївський бульвар», «Собор», «Базар», «Тютюнова фабрика Одеси», «Одеський порт», «Підйом затонулих при більшовиках пароплавів», «Відновлення літнього театру», «Пошкоджені будинки і будівлі», «Парад 10 травня», «Відкриття Миколаївського бульвару», «Інспекція в Рибниці», «Приїзд Губернатора з Києва», «Вшанування генерального примара», «Відкриття тютюнового виробництва», «Торжество відкриття нового бюро адвокатів», «День героїв у Дальнику і Аккаржа», «Відкриття румунського бульвару і парку», «Відкриття курсів школи пілотів», «Закладка аеродрому Татарки», «Відкриття виставки офіційного салону», «Відвідування маршалом Антонеску Одеси і його прибуття на аеропорт», «Маршал Антонеску на своій віллі», «Адміністративна конференція у Воронцовському палаці», «Відкриття їдалень для чиновників», «Прибут-

\footnotetext{
${ }^{37} 16$ октября 1941 - 16 октября 1943. Два года плодотворной деятельности Одесского Муниципалитета // Одесская газета (Одесса). 1943. 16 октября (№ 240). С. 3.

${ }^{38}$ Немецкий язык для чиновников Муниципалитета // Одесская газета (Одесса). 1943. 22 августа (№ 194). С. 3.

${ }^{39}$ Обзор деятельности Одесского Муниципалитета с 17-го октября 1941 г. до 1 марта 1942 года // Одесская газета (Одесса). 1942. 11 марта (№ 50). С. 5.
} 
тя Митрополита Віссаріона в Одесу», «Різдвяна ялинка в Одесі», «Торжество свята Хрещення», «Православна Неділя в Одесі», «Ловля скумбрії в лимані», «Купальний сезон в Аркадії», «Збір винограду в Трансністрії», «Види і життя Одеси». Крім цих фільмів, була ще пророблена робота з випуску пропагандистської фільмів, зокрема був знятий фільм «Царська наречена» ${ }^{40}$.

Крім перерахованих ініціатив відбувалася також й організація низки театральних установ. Було відкрито 4 театри й один цирк. Організовано театр Музичної Драми та Комедії і 2 літніх театру. Трохи згодом було відкрито ще два театри характеру «Театрів Мініатюр». Задля опису, збереження та розподілення майна культурних установ муніципалітету між новими установами було створено відділ інвентаризації.

Також за сприянням Одеського муніципалітету 16 вересня 1942 р. було вирішено відкрити книжкову крамницю для продажу книг. У жовтні 1942 р. відкрилась друга книжкова лавка, яка при здобула велику популярність серед інтелігенції міста. Про це свідчить і той факт, що за один рік було продано книг на суму 300000 РККС. Згодом обидві лавки були об'єднані в одну.

Візитною карткою Одеси був і Зоологічний сад. Територія саду, завдяки сприянню окупаційної влади, була збільшена майже вдвічі. Багато павільйонів, які постраждали від бомбардувань, були відновлені. За дозволом губернатора незабаром були також доставлені нові сорти з Німеччини й Асканії-Нова. Протягом одного року Зоологічний сад відвідало 10000 чол., більшість з яких з Румунського Королівства.

3 огляду на зростаючу кількість екскурсій з Королівства, з'явилась потреба в організації Будинку туризму, який мав би на меті прийом цих екскурсій і керівництво ними. Будинок туризму розташовувався по вул. Жуковській, $39^{41}$.

Гострою була тема національного питання, а особливо єврейського. Накази, розпорядження, інструкції румунської адміністрації дають нам уявлення про створення механізму дискримінації та фізичного знищення єврейського населення Одеси. 11 листопада 1941 р. очільник румунського уряду Іон Антонеску видав наказ № 23, за яким:

«...маючи на увазі необхідність організації проживання євреїв у певних місцях з метою забезпечення безпеки тилу; маючи також на увазі, що єврейське населення має власною працею та засобами забезпечити своє існування, наказуємо:

Ст. 1. Всі євреї, які прибули до Трансністрії з районів військових дій або жили раніше у Трансністрії і переселилися в інші місцевості у зв'язку з військовими діями, а також і ті євреї, які у подальшому будуть переселені, - зобов'язані підкорятися правилам, викладеним у цьому наказі.

Ст. 2. Інспекторат Жандармерії Трансністрії встановлює місцевості, де євреї можуть поселятися; розселення проводиться, відповідно до числа членів сімї̈, в оселях, що залишилися. Кожна єврейська сім'я, яка отримала житло, повинна привести його у належний стан й утримувати його у чистоті. Якщо число таких жител виявиться недостатнім, євреї можуть бути поселені і на приватних квартирах, особливо їм для того зазначених, з встановленням певної квартирної плати.

\footnotetext{
${ }^{40}$ Кинематографическая секция Дирекции культуры Одесского Муниципалитета // Одесская газета (Одесса). 1943. 12 октября (№ 236). С. 3.

${ }^{41}$ Обзор деятельности Одесского Муниципалитета с 17-го октября 1941 г. до 1 марта 1942 года // Одесская газета (Одесса). 1942. 11 марта (№ 50). С. 5.
} 
Ст. 3. Всі євреї, що входять до складу кожного такого поселення або громади, повинні бути занесені в особливий список, де вказується: прізвище, ім'я, національність, релігія, вік, професія, місцевість, звідки прибув. Кожному єврею буде виданий відповідний документ 3 перерахуванням всіх вищенаведених даних.

Ст. 4. Жоден єврей не може залишити поселення, в якому йому призначено місце проживання, без особливого на те дозволу, виданого районним або повітовим префектом (начальником поліції).

Ст. 5. Всі євреї, що входять до складу одного поселення, утворюють колонію, яка управляється начальником колонії, який призначається претором району з середовища поселенців. Помічниками начальника колонії є керівники груп: начальник колонії призначає для кожної групи (в 20 чоловік) керівника, який несе відповідальність за наявність в групі всіх її членів, піклується про благополуччя їх і повідомляє про кожне порушення, допущене будь-ким з групи. Начальник колонії і керівники груп відповідають особисто за присутність всіх євреїв в колонії і за їх виконання розпоряджень адміністрації та жандармерії.

Ст. 6. Начальник колонії зобов'язаний подати списки всіх членів колонії, які володіють будь-якою спеціальною професією, всіх ремісників і взагалі всіх осіб, здатних до праці. На підставі списків, поданих начальником колонії, міський голова або сільський староста організовує працю у колонії і в місті або селі у наступному вигляді: євреї, які володіють будь-якої спеціальної професією будуть знаходитися у розпорядженні управління колонії і будуть залучатися до роботи по мірі необхідності; майстри-ремісники будуть виконувати роботу, яка призначається імм відповідно до їх спеціальності; всі інші (особи некваліфікованої праці) будуть знаходитися у розпорядженні міських або сільських властей і будуть використовуватися на різних роботах для потреб колонії, або міста або села, або на інших роботах для суспільних потреб. Зокрема, вони будуть використані на польових роботах, на роботах з благоустрою доріг і мостів, по заготівлі лісу і дров, каменю й інших матеріалів. За пророблений робочий день видається продовольча картка в 2 марки, а для осіб некваліфікованої праці - в 1 марку. Органи жандармерії зобов'язані постійно перевіряти і контролювати стан єврейських колоній, доводячи до відома керівних органів про всі виявлені порушення.

Ст. 7. Залучення євреїв на роботу з однієї колонії в іншу проводиться з дозволу районного або повітового префекта. Залучення для робіт фахівців з одного району чи повіту в інший проводиться тільки з дозволу Директора відділу праці при Цивільному губернаторові.

Ст. 8. Кожен єврей, виявлений за межами своєї колонії без належного на те дозволу, буде розглядатися як шпигун і негайно покараний на підставі військових законів, що діють у воєнний час.

Ст. 9. Євреї-фахівці можуть бути з дозволу Губернатора використані на всіх роботах по відновленню промисловості, яка постраждала в результаті війни.... ${ }^{42}$.

Згідно декрету № 1798 від 21 червня 1941 р. військово-польової юстиції, всі особи єврейського походження, які проживали в Одесі, зобов'язані до 12 години 19 листопада 1941 р. повідомити про всі, наявні у них дорогоцінні предмети (платина, золото, срібло) в будь-якій формі: коштовності, монети, побутові предмети тощо та здати ці предмети разом зі своєю заявою поліції ${ }^{43}$.

Вдавалася румунська влада і до фізичного знищення єврейського населення. Зок-

\footnotetext{
${ }^{42}$ Главное военное командование управление гражданского губернатора Транснистрии. Приказ № 23 // Одесская газета (Одесса). 1941. 24 декабря (№ 20). С. 5.

${ }^{43}$ Приказ № 2 Командующего войсками г. Одессы // Одесская газета (Одесса). 1941. 17 ноября (№ 8). С. 2.
} 
рема, через партизанську диверсію (порохові склади на 3-й Люстдорфській дорозі) відбулося масове знищення євреїв. 24 жовтня 1941 р. серед місцевого населення Одеси поширився наказ командувача румунськими військами М. Генералу, що «...за кожного вбитого офіцера чи румунського чиновника будуть розстріляні 200 більшовиків, а за кожного румунського солдата по 100 більшовиків...» ${ }^{44}$.

Під расову дискримінацію потрапляли не тільки люди семітського походження. На території Одеси суворо заборонялося циганам продавати будь-які предмети одягу або ж домашнього вжитку. Також жителям міста не дозволялося купувати будь-які речі у циган. Цигани, що продавали мешканцям і мешканці, які купували у циган, доставлялися поліцією до військового претора та покарані тюремним ув'язненням строком від 2 до 6 місяців ${ }^{45}$.

Декотру інформацію про життя в окупованій Одесі можна знайти на сторінках газети «Голос». Зокрема, там писалося:

«...Досить тільки зазначити, що в Одесі є тепер коло 6000 крамниць. Головна торгова вулиця міста Дерибасівська - сповнена комісійних крамниць. По вітринах бачимо найрізноманітніші побутові речі: велосипеди, жіночі сукні, порцеляну, черевики, хутра, ікони, прикраси, килими. Власне, легше було б скласти список речей відсутніх у крамницях. Поруч зі старим лахміттям можна бачити справжні скарби. Поруч з господарською відбудовою відновилося й культурне життя. Працювали усі школи включно до університету. Виходило 4 часописи, відкрито 2 драматичні театри та опера» ${ }^{46}$.

Зовсім іншу, менш ідилістичну картину подає газета «Нова доба» (Берлін), цитуючи шведського професора Густава Боландера, який, подорожуючи, відвідав Одесу:

«...Майже вся Одеса стала жертвою військових операцій у 1941 р. Ще й досі міські будинки мають вигляд переважно руїн. Зовсім уціліла тільки опера, в якій щодня відбуваються гарні вистави. Театр переповнений глядачами. Публіка вбрана здебільшого дуже вбого, але одяг цілий і чистий. Одеса зруйнована, особливо артилерією. Деякі будинки вже частково відремонтовано: вставлено нові вікна, двері тощо» ${ }^{47}$.

Під час румунської окупації, Одесу відвідували й іноземні дипломати. Зокрема «Одесская газета» повідомляла, що:

«...14 червня 1943 р. Генеральний примар Одеського муніципалітету пан Герман В. Пинтя прийняв посла Швейцарської республіки в Бухаресті пана де Кека у своєму кабінеті. Пан міністр ознайомився з планами дій румунської адміністрації в Трансністрії і висловив своє повне задоволення всім йому продемонстрованим і побажав процвітання Румунії і Трансністрії...» ${ }^{48}$.

3 огляду, на деякий успіх румунської адміністрації у розбудові Одеси, 10 травня

\footnotetext{
${ }^{44}$ Остащук В.I. Здійснення антисемітської ідеологічної політики румунською адміністрацією в Одесі (19411944 рр.) // Гілея: наук. вісн.: зб. наук. пр. 2019. Вип. 140 (№ 1), Ч. 1: Істор. науки. С. 76.

45 ДАМО. Ф. Р-1651. Оп. 1. Спр. 3. Арк. 21.

${ }^{46}$ Мирна Одеса // Голос (Берлін). 1943. 7 березня (№ 10). С. 3.

${ }^{47}$ Життя в Одесі // Нова доба (Берлін). 1943. 19 вересня (№ 38) С. 3.

${ }^{48}$ Прием Генеральным Примарем Одесского Муниципалитета министра Швейцарской республики // Одесская газета (Одесса). 1943. 17 июня (№ 137). С. 3.
} 
1943 р. проф. Г. Алексяну, губернатор Трансністрії, підписав постанову за № 2058 з наступним змістом:

«Бачачи працю і старанність, прикладені примарем Одеського муніципалітету, який в такий короткий термін здійснив на славу Батьківщини важливу справу міського управління та бажаючи підбадьорити цю плідну діяльність в силу повноти влади, пан Герман Пинтя, примар Одеського муніципалітету з 10 травня 1943 р. підвищується в чин генерального примара цього муніципалітету. Помічники примара: Кіореску Володимир, Сінікліу Елефтерій, Відрашку Костянтин, Заєвлошін Михайло і Кундерт Володимир - підвищуються в чин примарів секторів, починаючи з цього ж числа».

На підставі цієї постанови Генеральний примар Герман Пинтя 25 травня підписав рішення за № 578 , яке стосувалося організації керівництва примаря Одеського муніципалітету, за ст. 2 згаданої постанови, в Одеському муніципалітеті засновувалося наступні 5 секторів:

- Економічний сектор. Цей сектор матиме в своєму віданні дирекцію постачання.

- Сектор комунальних підприємств. Цей сектор матиме: 1) Електротехнічну дирекцію; 2) Дирекцію водопроводу і каналізації; 3) Дирекцію трамвая; 4) Дирекцію дач, парків і садів.

- Сектор Культури і комунального майна. Цей, сектор матиме: 1) Дирекцію культури; 2) Дирекцію нерухомості; 3) Інвентарну дирекцію;

- Сектор Цивільного стану;

- Технічний сектор ${ }^{49}$.

Наступний 1944 р. став останнім роком румунської окупації і роком важливих кадрових перестановок в уряді. У 1944 р. через складну військову ситуацію маршал румунської держави Антонеску скасовує посаду цивільного губернатора Трансністрії. Вся влада у Трансністрії переходила під управляння військового відомства, на чолі якого стояв генерал Г. Потопяну

1 лютого 1944 р. спеціальним поїздом на Одеський вокзал прибув генерал Г. Потопяну в супроводі полковника Поповича, майора Васіліу та майора Іонеску. Генерала зустрічали: генеральний секретар Черкавський, генерал Тінку, генерал Стоєнеску, генеральний інспектор жандармерії, полковник Ілієску, генеральний примар м. Одеси Герман Пинтя, директор Губернаторства і повітові префекти. Генеральний секретар Черкавський привітав генерала Потопяну з благополучним прибуттям, а примар Одеси Г. Пинтя зустрів його з хлібом і сіллю. Генеральний секретар Черкавський представив нового керівника провінції між Бугом і Дністром директорам і префектам, після чого генерал Потопяну разом зі своєю свитою попрямував у губернаторську резиденцію. На другий день о 12 годині у Воронцовському палаці відбулося торжество вступу пана генерала Г. Потопяну в нову посаду ${ }^{50}$.

Ще про одну важливу кадрову перестановку передає газета «Молва». 16 грудня 1944 р. у приміщенні Одеського муніципалітету відбувся прийом на честь полковника

\footnotetext{
${ }^{49} 16$ октября 1941 - 16 октября 1943. Два года плодотворной деятельности Одесского Муниципалитета // Одесская газета (Одесса). 1943. 16 октября (№ 240). С. 3.

${ }^{50}$ Торжество вступления в должность нового руководителя провинции между Днестром и Бугом // Одесская газета (Одесса). 1944. 8 февраля (№ 31). С. 1.
} 
Мензінга, який довгий час займав посаду начальника німецького штабу по зв'язку в Трансністрії та співробітника румунської адміністрації, однак отримавши нову відповідальну посаду вже у Німеччині, залишав Трансністрію. На честь високого співробітника у палаці муніципалітету Одеси відбувся прийом у присутності: професора Г. Алексяну, Губернатора Трансністрії; Митрополита Віссаркока; консула Схефані; генерала Стоєнеску, Генерального примара муніципалітету м. Одеси Германа Пинті; повітового префекта Велческу; префекта поліції полковника Мітріка; інженера Чубука; директора юстиції Метваського ${ }^{51}$.

Висновки. Таким чином, узагальнюючи все вищесказане, можна зробити висновок, що Одеському муніципалітету Трансністрії на чолі з генеральним примарем Германом Пинтя протягом 1941-1944 рр. вдалося відновити після військових дій електропостачання та трамвайний рух у місті, налагодити постачання води та продовольства, к декотрій мірі підняти зруйновану економіку, провести фінансову реформу, відкрити медичні установи, реформувати шкільну освіту, налагодити поштовий зв'язок. Досить серйозні зміни відбулися у сфері юстиції та правоохоронних органів. Зокрема, було створено цивільне та військове судочинство, жандармський інспекторат і поліцейські органи управління, а також засновано Бюро адвокатів та нотаріальні контори. Культурна політика ознаменувалася відкриттям шкіл і Народного університету, заснуванням низки газет, реорганізацією фотокінематографічної секції тощо.

\section{Lidiia Bilichenko}

\section{Activities of the Odessa Municipality Of Transnistria (1941-1944)}

Abstract: The article examines the activities of the Odessa municipality during the Romanian occupation of Odessa in 1941-1944. It is proved that the activities of the municipality focused mainly on the following aspects: reforming the administrative branch, economic recovery, reforming law enforcement, health and education. Also, the officials of the Odessa municipality faced a very difficult task to restore the more or less normal functioning of the city. In the autumn of 1941, Odessa was a horrible picture after the war: a power plant was blown up, a water supply system, a radio station, a telephone exchange, shops were looted, warehouses, bakeries and mills were destroyed, smoke from fires, bridges were destroyed, and medical facilities were destroyed. It is established that during 1941-1944 the Odessa municipality of Transnistria, headed by the mayor General Herman Pinta during 1941-1944 managed to restore electricity and tram traffic in the city after the war, to establish water and food supply, to some extent to raise the destroyed economy, to carry out financial reform, to open medical institutions, to reform school education, to establish postal communication. Quite serious changes have taken place in the field of justice and law enforcement. In particular, a civil and military judiciary, a gendarmerie inspectorate and police authorities have been established, as well as a Bureau of Lawyers and notaries. Cultural policy was marked by the opening

\footnotetext{
${ }^{51}$ Полковник Мензинг // Молва (Одесса). 1943. 16 декабря (№ 311). С. 1.
} 
of schools and the People's University, the founding of the «Odessa newspaper», the reorganization of the photo-cinematographic section and more. The topic of the national question, especially the Jewish one, was acute. Orders, directives, instructions of the Romanian administration give us an idea of creating a mechanism of discrimination and physical extermination of the Jewish population of Odessa.

Keywords: World War II, occupation, Transnistria, Odessa municipality, press 